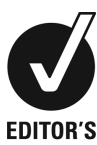

CHOICE

\title{
The devastating effects a fire burn in a child
}

Şeref Istek

Department of Ophthalmology, Hakkari State Hospital, Hakkari, Turkey

\section{Correspondence to} Dr Şeref Istek, serefistek@hotmail.com

Accepted 29 April 2015

\section{SUMMARY}

Burn injuries are a serious global public health concern with significant worldwide mortality and morbidity rates. Burns are among the most devastating of all injuries, with outcomes ranging from physical impairment and disability to emotional and mental consequences. Paediatric burns requiring treatment often incur significant health and opportunity costs, and frequently result in death or long-term disability. A recent systemic review showed that almost $50 \%$ of patients hospitalised with severe burns in Europe were younger than 16 years of age, and nearly $60 \%$ were male. This report discusses the case of a 2-year-old boy with second and thirddegree skin burns over almost $45 \%$ of his body, including his head and arms, who presented to the eye clinic at the State Hospital in Hakkari 1 month after a fire burn accident. Both eyes had been burnt and the bilateral anterior chambers had been injured so badly that the patient was left blind.

\section{CASE PRESENTATION}

The patient was a 2-year-old boy who was blind in both eyes as a result of a serious thermal burn. The victim's mother said: "I was out shopping and had left my baby at home sleeping near the electric heater. When my neighbours called me, I returned to my house which was partly in flames. The firemen had saved the child before it was too late. There were serious burns to his body, especially his head, and his left hand seemed to have come off. Because we are poor and have no health insurance, I could not take the child to the hospital right away. It was only one month later that I was able to take the child to an ophthalmologist". The skull, face and upper body of the patient (approximately $45 \%$ of his entire body) had been burned, and both wrists had separated from the lower arms. His nose, ears, eyelids, conjunctivas and bilateral ocular surfaces had been burned. The anterior chambers were completely destroyed. The corneas were opaque bilaterally, and the left eye was so badly damaged that it had shrunk. Figure 1 shows the patient's skull, ears, face, eyelids and ocular surfaces. The patient was prescribed povidone-polyvinyl alcohol (Refresh Single Dose) artificial eye drops, ofloxacin (Exocin) anti-bacterial eye drops and bacitracin-neomycin (Thiocilline) ophthalmic ointment for the ocular surface to prevent secondary bacterial infection. The patient's respiratory, circulatory and neurological systems had been previously examined by paediatricians. Plastic surgeons had removed necrotic tissue and grafted skin on to his scalp. The specialist referral centre did not propose additional treatment or reconstruction of the ocular surfaces, trunk or arm. The patient

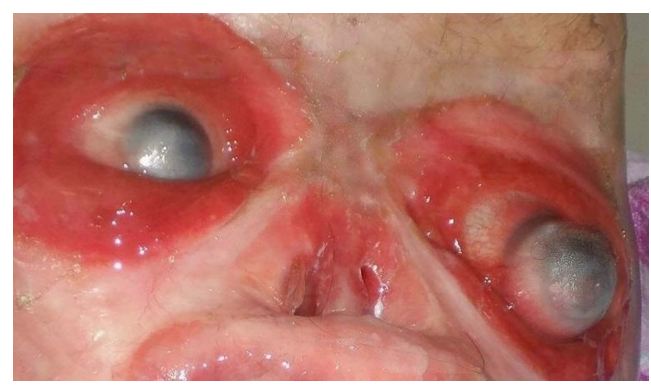

Figure 1 The patient's face, eyelids and ocular surface badly affected by the thermal fire burn.

was left blind because the bilateral anterior segments had been so severely damaged.

\section{GLOBAL HEALTH PROBLEM LIST}

Burn-related disabilities are a significant health problem. Ocular and plastic reconstruction of fire burns with skin grafts varies according to the location and degree of burn. Burns may cause blindness if the anterior chambers are affected. Small children must be protected from thermal burns because they are especially vulnerable to fires burns and accidents. Public awareness should be raised to help prevent house fires. Patients with low socioeconomic status are assumed to be more affected by accidental fire burns. Populations with low socioeconomic status have poor access to preventive programmes and healthcare providers for various reasons. Specialist burns services and centres are essential for proper and timely treatment of burn patients.

\section{GLOBAL HEALTH PROBLEM ANALYSIS}

Burn injuries represent a significant public health concern in both developing and developed countries. ${ }^{1}$ A large percentage of burns which usually occur accidentally could be minimised by applying some effective prevention measures. ${ }^{2}$ Burns are closely related to significant mortality and morbidity rates worldwide and are among the most devastating of all injuries with outcomes spanning the spectrum from physical impairments and disabilities to emotional and mental consequences. ${ }^{3}$ Paediatric burns requiring healthcare often incur significant health and opportunity costs, death or long-term disability. ${ }^{4}$ In Europe, the annual incidence of severe burns from 1985 to 2009 ranged from 0.2 to $2.9 / 10000$ population, with a decreasing trend over time. Almost $50 \%$ of patients were younger than 16 years of age, and nearly $60 \%$ were male. ${ }^{5}$ Eyelid involvement is common in facial burns. Over 50\% of burnt eyelids developed eyelid contractures and eyelid ectropion 
which may lead to loss of protection of the cornea. ${ }^{6}$ About $15 \%$ of eyelid burn patients go blind if not treated promptly. ${ }^{7}$ Ocular fire burns can result in various complications including eyelid contracture, conjunctivitis, corneal epithelial defects, corneal ulcers, conjunctival cell migration, corneal perforation, corneal scarring, cataract formation, increased intraocular pressure, glaucoma, retinal detachment, decreased vision and even blindness. ${ }^{7}$ Good results may be obtained following mild and moderate injury, but in severe cases complex medical treatment and rehabilitation, including corneal transplantation, are required.

Our case concerned a 2-year-old boy badly burned in an accidental fire caused by an electric stove in his home. The bilateral anterior chambers were severely affected and he was blind bilaterally. Burns in males are twice as frequent as in females $(68.0 \%$ vs $31.9 \%) .{ }^{1}$ Hot liquids $(45.8 \%)$ are the most common cause of burns, followed by open flames (27.5\%). ${ }^{1}$ Burn degree and total body surface area affected is strongly associated with mortality. Patients over the age of 70 have the worst prognosis and the 0 1 -year-old age group the best prognosis. Those who experience burns over $90 \%$ of their body and are over the age of 70 have the highest mortality. ${ }^{1}$ According to Hussain and Dunn, ${ }^{8}$ accidental house fires cause nearly half (49\%) of the injuries resulting in death. Extensive destruction with severe loss of soft tissue and shortening or amputation of the extremities are seen only in $15 \%$ of accidental fire burn deaths. ${ }^{9}$

Acute thermal injury results in immediate cell death. The thermal stimulus triggers the inflammatory process by activating inflammatory cells and stimulating rapid accumulation of extravascular fluid in ocular tissue. ${ }^{10}$ The severity of thermal injury is closely associated with the energy of and the length of exposure to the fire. Prognosis depends on the degree of tissue damage. Thermal burns can lead to thermal penetration and thermal necrosis of epithelial cells. ${ }^{11}$ Hot liquids, hot gases, molten metals or ultraviolet rays can cause thermal damage. Burns damage tissues mainly by coagulating tissue proteins, and secondly, through ischaemic vascular damage.

Acute treatment of thermal burns starts with cleaning the burned eyelashes and tissues. Topical ophthalmic antibiotics and artificial tear preparations are used to protect the ocular surface from bacterial infection and dryness. Eyelid burns may cause eyelid ectropion and eyelid contracture. ${ }^{6}$ In severe burns, tarsorrhaphy used to be advised because of the protective and moisturising effect of the upper eyelid, but is not now recommended due to its effect on lid retraction. ${ }^{12}$ Tissue grafting is essential for reconstructing the ocular surface and adnexa in severe ocular burns, but timing of the operation is controversial. Most surgeons advise early tissue grafting, but early complications such as plasma exudation and tissue infection can affect its success. However, delayed tissue grafting can result in hypertrophic scar formation, asymmetry or ectropion which can damage the cornea. ${ }^{13}$ Partial-thickness or full-thickness skin grafts are commonly used in the acute treatment of eyelid burns. According to Lille et al, the use of full-thickness instead of splitthickness skin grafts may help lower the incidence of ectropion and reduce corneal exposure. ${ }^{14}$ The authors advise the use of thicker rather than thinner grafts for lower contracture rates because this increases resistance to trauma. In our case, neither we nor the tertiary centre performed any grafting on the ocular surface because there was no tissue with normal vascularisation and nutrition.

National efforts to prevent burn injuries require information on epidemiological characteristics and risk factors. The incidence of childhood fire burns in Turkey is unknown because of inadequate records. It is important to clearly define the social, cultural and economic factors which contribute to burn cases. Socio-demographic factors linked to an increased incidence of burns include low household income, living in a deprived area, living in rented accommodation, young mothers, single-parent families and children from ethnic minorities. The parental educational level, parental occupation, and the type and size of accommodation are also important. ${ }^{15}$ The risk is greater in children who are exposed to a number of these factors. Identification of these factors may play a role in enhancing burn prevention programmes and preventive practices. Household fires can be prevented. Tackling burns must focus on public sector intervention, education, prevention, healthcare capacity and access to care, and on socioeconomic problems and situations. ${ }^{16}$ Increased efforts in all spheres are likely to lead to a significant reduction in burn-related death and disability. ${ }^{16}$ Public education is the most important factor to prevent fire burns. A combined approach in which people receive fire prevention education in schools, at home or in public health centres may be effective for improving fire prevention knowledge and behaviour. Environmental measures such as the use of smoke detectors and carbon monoxide detectors, turning off domestic appliances when not in use, reducing the temperature of home devices, monitoring children more closely, better planning of homes to reduce hazards, and vigilance by parents may prevent burn injuries. The establishment of a national programme would help ensure sufficient funds are available and allow coordination of the efforts of district, regional and tertiary care centres. It could also set up compulsory reporting of all burn admissions to a central registry, and these data could then be used to evaluate strategies and prevention programmes directed at behavioural and environmental change. ${ }^{3}$ If preventive programmes are successful, there will be less need for medical treatment. If parents were more careful, we would probably not encounter such cases that result in permanent blindness. Burns are a serious condition and easily prevented with very simple measures.

\section{Patient's perspective}

My carelessness could have caused the child's death. Although my husband and I are very upset that our child has lost both eyes and his left wrist, we are glad our son has survived.

Learning points

Public health and safety education can prevent life-threatening burns.

- Facial burns are an important cause of avoidable blindness.

- Preventive actions reduce the need for medical treatment.

Competing interests None declared.

Patient consent Obtained.

Provenance and peer review Not commissioned; externally peer reviewed.

\section{REFERENCES}

1 Haik J, Liran A, Tessone A, et al. Burns in Israel: demographic, etiologic and clinical trends, 1997-2003. Isr Med Assoc J 2007;9:659-62.

2 Groohi B, Alaghehbandan R, Lari AR. Analysis of 1089 burn patients in province of Kurdistan, Iran. Burns 2002;28:569-74. 
3 Atiyeh BS, Costagliola M, Hayek SN. Burn prevention mechanisms and outcomes: pitfalls, failures and successes. Burns 2009;35:181-93.

4 Parbhoo A, Louw QA, Grimmer-Somers K. Burn prevention programs for children in developing countries require urgent attention: a targeted literature review. Burns 2010;36:164-75.

5 Brusselaers N, Monstrey S, Vogelaers D, et al. Severe burn injury in Europe: a systematic review of the incidence, etiology, morbidity, and mortality. Crit Care 2010;14:R188.

6 Stern JD, Goldfarb IW, Slater H. Ophthalmological complications as a manifestation of burn injury. Burns 1996;22:135-6.

7 Kuckelkorn R, Schrage N, Keller G, et al. Emergency treatment of chemical and thermal eye burns. Acta Ophthalmol Scand 2002;80:4-10.

8 Hussain A, Dunn K. Burn related mortality in Greater Manchester: 11-year review of Regional Coronial Department Data. Burns 2015;41:225-34.

9 Bohnert M, Schmidt U, Perdekamp MG, et al. [Extent of burn lesions-an analysis of 68 burned cadavers]. Arch Kriminol 2001;207:104-13.
10 de Bandt JP, Chollet-Martin S, Hernvann A, et al. Cytokine response to burn injury: relationship with protein metabolism. J Trauma 1994;36:624-8.

11 Monsudi KF, Ayanniyi AA. A 14-year-old girl who regained normal vision after bilateral visual impairment following hot water injury to the eyes. Saudi f Ophthalmol 2011;25:207-10.

12 Liu $\mathrm{H}$, Wang $\mathrm{K}$, Wang $\mathrm{Q}$, et al. A modified surgical technique in the management of eyelid burns: a case series. J Med Case Rep 2011;5:373.

13 Imuagwu FC, Wilson D, Bailie $F$. The use of skin grafts in postburn contracture release: a 10-year review. Plast Reconstr Surg 1999;103:1198-204.

14 Lille ST, Engrav LH, Caps MT, et al. Full-thickness grafting of acute eyelid burns should not be considered taboo. Plast Reconstr Surg 1999;104:637-45.

15 Alnababtah K, Khan S, Ashford R. Socio-demographic factors and the prevalence of burns in children: an overview of the literature. Paediatr Int Child Health 2014:2046905514Y0000000157.

16 Gupta S, Mahmood U, Gurung S, et al. Burns in Nepal: a population based national assessment. Burns 2014.

Copyright 2015 BMJ Publishing Group. All rights reserved. For permission to reuse any of this content visit http://group.bmj.com/group/rights-licensing/permissions.

BMJ Case Report Fellows may re-use this article for personal use and teaching without any further permission.

Become a Fellow of BMJ Case Reports today and you can:

- Submit as many cases as you like

- Enjoy fast sympathetic peer review and rapid publication of accepted articles

- Access all the published articles

- Re-use any of the published material for personal use and teaching without further permission

For information on Institutional Fellowships contact consortiasales@bmjgroup.com

Visit casereports.bmj.com for more articles like this and to become a Fellow 